\title{
THE DIVERSITY OF THE PLACE OF RESIDENGE OF STUDENTS AND THEIR LEVEL OF PHYSICAL ACTIVITY
}

\author{
Józef Bergier, 1, A, B, C, D Barbara Bergier, 1, A, B, D Ewelina Niźnikowska, 1, A, B, D Ján Junger, 2, A \\ Ács Pongrác, ${ }^{3, \mathrm{~A}}$ Karel Frömel, ${ }^{4, \mathrm{~A}}$ Adam Szepeluk ${ }^{5, \mathrm{C}}$ \\ ${ }^{1}$ Department of Physical Education and Physiotherapy, Faculty of Health Sciences, Pope John Paul II State School of Higher Education in Biała \\ Podlaska, Poland \\ 2 University of Presov in Presov, Slovakia \\ ${ }^{3}$ University of Pecs, Hungary \\ ${ }^{4}$ Palacky University in Olomunec, Czech Republic \\ ${ }^{5}$ Innovation Research Centre, Pope John Paul II State School of Higher Education in Biała Podlaska, Poland \\ ${ }^{\text {A }}$ Study Design; ${ }^{\mathrm{B}}$ Data Collection; ${ }^{\mathrm{C}}$ Statistical Analysis; ${ }^{\mathrm{D}}$ Manuscript Preparation \\ Address for correspondence: \\ Barbara Bergier \\ Pope John Paul II State School of Higher Education in Biała Podlaska \\ Sidorska 95/97, 21-500 Biała Podlaska, Poland \\ E-mail: barbara.bergier@wp.pl
}

\begin{abstract}
Ahstract. The aim of the research was to study the diversity of the level of physical activity among the students according to their place of residence: a house (a detached house) or a flat (a residential block). The research was carried out in 2015 among 730 students ( 373 women and 357 men) of John Paul II State School of Higher Education in Biała Podlaska (PSW). The method used in the research was the International Physical Activity Questionnaire (IPAQ) in its long version. The results have shown that there were no significant differences in the overall level of physical activity of both men and women according to their place of residence.

However, significant differences have been noticed among female and male students as regards the physical activity connected to housework in favour of people living in houses. The same correlation was observed in favour of women living in flats (residential blocks).
\end{abstract}

Key WOrdS: physical activity, IPAQ, students, place of residence

\section{Introduction}

The research concerning physical activity of Polish students by means of the International Physical Activity Questionnaire (IPAQ) becomes more and more popular (Bergier, Kapka-Skrzypczak, Biliński, Paprzycki, Wojtyła, 2012; Biernat 2011; Mynarski, Rozpara, Czapla, Garbaciak, 2009). Collecting research data using the same tool (IPAQ) in many different countries is of a particular significance (Ainsworth et al. 2006; Bergier, Kapka-Skrzypczak, Biliński, Paprzycki, Wojtyła 2012; Crinière et al. 2009; Ekelund et al. 2006; Gomez, Duperly, Lucumí, Gamez, Venegas, 2005; Sebastiano et al. 2012; Soguksu 2011; Tsos, Bergier, Bergier 2014). The researches on physical activity of students that concern searching for the factors determining this activity such as eating habits (Bergier, 
Kubińska, Bergier, 2011; Bergier, Bergier, Tsos., 2015; Pengpid, Peltzer, 2013; Szczodrowska, Krysiak, 2013), sex (Bergier, Stępień, Niźnikowska, Bergier, 2014; Frömel. Górna,2001; Mynarski, Rozpara, Czapla, Garbaciak, 2009; Suchomel, Sigmundova, Frömel, 2008; Sygit 2009) and local infrastructure (Bauman et al. 2012; Cerin, Vandelanotte, Leslie, Merom, 2008; McCormack, Shiell, 2011) are also of a particular value. The factor connected to the place of residence during studies, on the campus or a family house, is analyzed relatively rarely (Baar, Romppel, Igel, Brahler, Grande, 2014; Brevard, Ricketts, 1996; Peachey, Baller, 2015).

\section{Research methodology}

The aim of the research was to study the diversity of the level of physical activity among the students according to their place of residence: a house (a detached house) or a flat (a residential block).

It must be presupposed that living in a house creates more occasions for physical activity, for example as far as housework, gardening or taking care of family members are concerned. There is no doubt that the differentiation of the students' physical activity can occur in case of living on the university campus. Taking into consideration the fact that only $4,8 \%$ of the respondents live on the university campus, this place of residence was not taken into consideration in the analysis of research results.

\section{Material and Methods}

730 students of John Paul II State School of Higher Education in Biała Podlaska (PSW), representing 10 different areas of study, participated in the research carried out in 2015. The demographic characteristic including sex, place of residence and area of study is presented in Table 1. The method used in the research was the International Physical Activity Questionnaire (IPAQ) in its long version

Table 1. Demographic characteristics of respondents

\begin{tabular}{ccc}
\hline \multicolumn{3}{c}{ Sex } \\
\hline \multicolumn{3}{c}{ men } \\
\hline 373 & \multicolumn{3}{c}{$(457.90 \%)$} \\
$(51.10 \%)$ & Place of residence \\
\hline \multicolumn{3}{c}{ campus } \\
\hline house & flat & 35 \\
\hline 447 & 248 & $(4.80 \%)$ \\
$(61.20 \%)$ & $(34.00 \%)$ & technical \\
\hline \multicolumn{3}{c}{ Area of study } \\
\hline humanistic & medical & $(33.01 \%)$ \\
\hline 261 & 228 &
\end{tabular}

\section{Results}

\section{Students' level of physical activity}

The value of overall physical fitness of students was 6363.5 MET-min/week. In certain areas of activity the following values were noted: work/study - 2068.8 MET-min/week, sports - 1.621.6 MET-min/week, locomotion 1402.2 MET-min/week, house and surroundings - 1270.9 MET-min/week (Figure 1). 


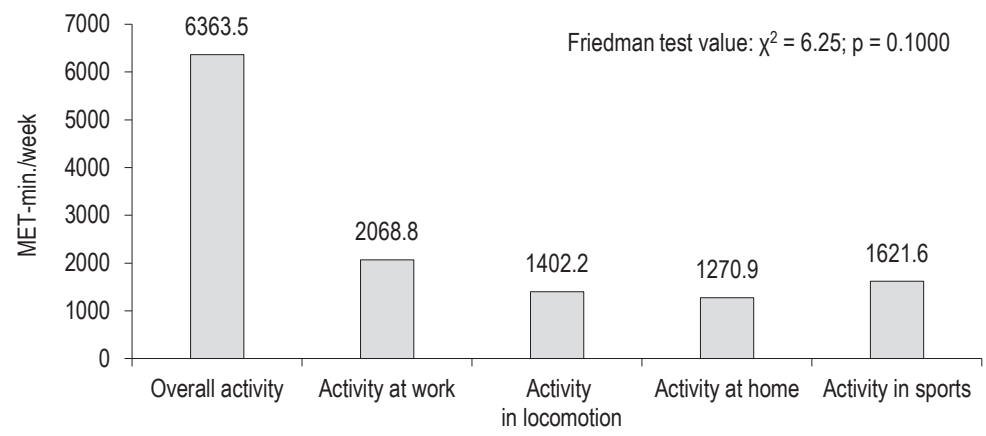

Figulp 1. Areas of physical activity of students

\section{Students' level of physical activity according to their place of residence}

Taking into consideration the fact that only $4.8 \%$ of examined students lived on the campus, only the students living in flats and houses were included in the research. Students who live in houses are characterized by higher overall physical activity (6609.2 MET-min/week) than those who live in flats (5680.2 MET-min/week), however the difference is not statistically significant. Students who live in houses are characterized by significantly higher physical activity in the area of housework (Figure 2, Table 2). The data from the three levels of students' physical activity, high, moderate and low, did not show any statistically significant differences between the compared groups (Figure 3).

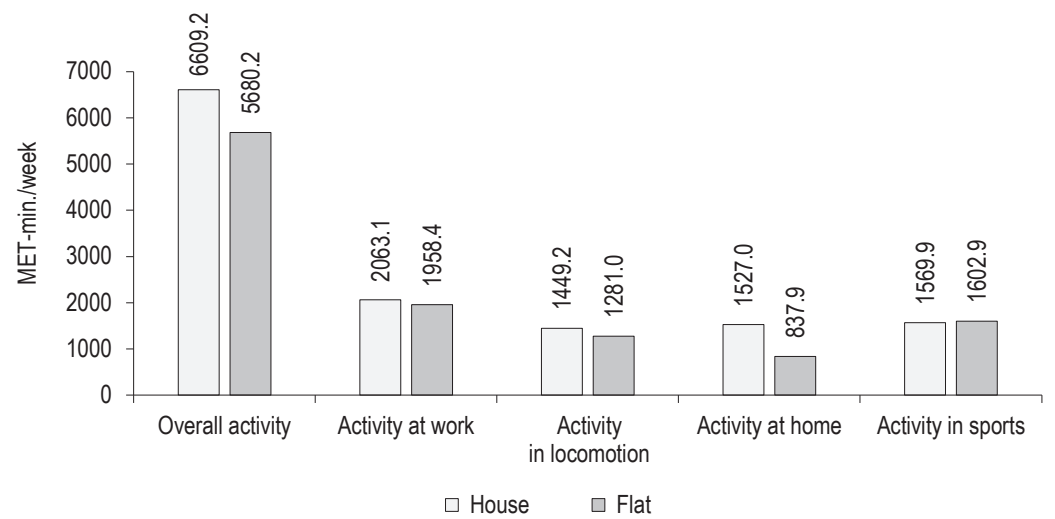

Figure 2. Areas of physical activity of students according to their place of residence 
Table 2. Differentiation of the areas of student' physical activity according to their place of residence

\begin{tabular}{|c|c|c|c|c|}
\hline \multicolumn{5}{|c|}{ Mann-Whitney U test } \\
\hline \multirow{2}{*}{ area of activity } & \multicolumn{2}{|c|}{ rank-sum } & \multirow{2}{*}{ Z } & \multirow{2}{*}{$p$} \\
\hline & house & flat & & \\
\hline Overall activity & 82,395 & 159,466 & -1.54 & 0.1232 \\
\hline Activity at work & 84,952 & 156,908 & -0.54 & 0.5913 \\
\hline Activity in locomotion & 84,588 & 157,273 & -0.68 & 0.4984 \\
\hline Activity at home & 71,919 & 169,942 & -5.67 & $0.0000^{*}$ \\
\hline Activity in sports & 88,184 & 153,677 & 0.74 & 0.4575 \\
\hline
\end{tabular}

'Significant differentiation at $p<0.05$.

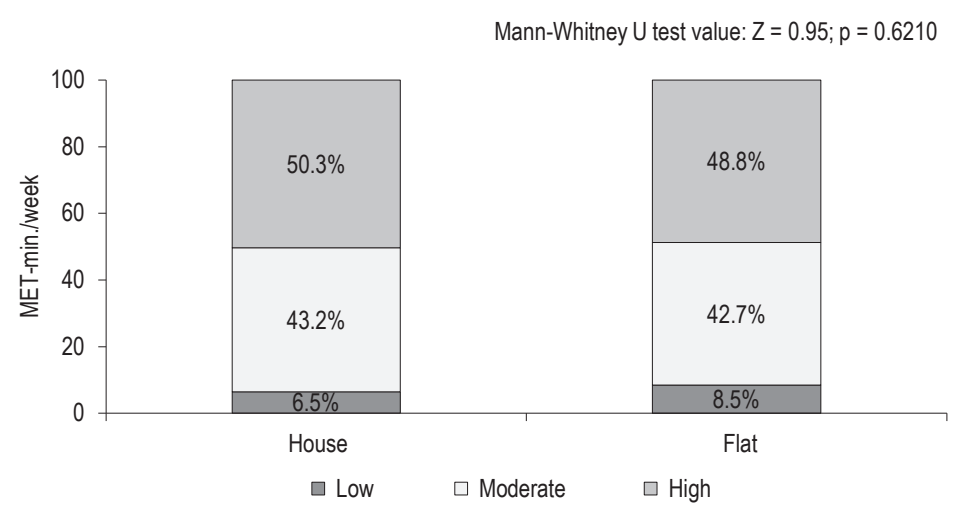

Figure 3. The level of students' physical activity according to their place of residence

\section{The level of physical activity of male students}

The studying men are characterized by high level of physical activity - 7581.4 MET-min/week with the highest values connected to the activity at work/study - 2625.1 MET-min/week and in sports - 2024.1 MET-min/week, and the lowest values concerning the activity in locomotion - 1558.1 MET-min/week and housework. Substantially the highest physical activity was observed in activity at work/study (Figure 4).

Students living in houses are characterized by higher overall physical activity - 8020.8 MET-min/week than their peers who live in flats - $6597.5 \mathrm{MET}$-min/week, however, the differences are not statistically significant.

The only statistically significant difference in favour of higher physical activity of men living in houses was observed in the area of housework (Figure 5, Table 3). The comparison of both analyzed groups according to their place of residence did not reveal any significance of differences in their physical activity levels (Figure 6). 


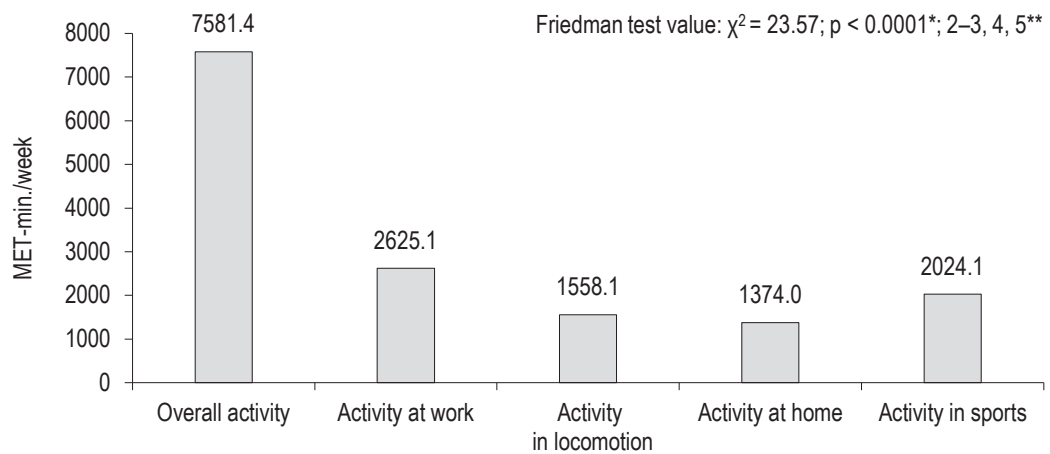

* Significant differentiation at $p<0.05$.

** Areas among which statistically significant differences occur $p<0.05$.

Figure 4. Areas of physical activity of men

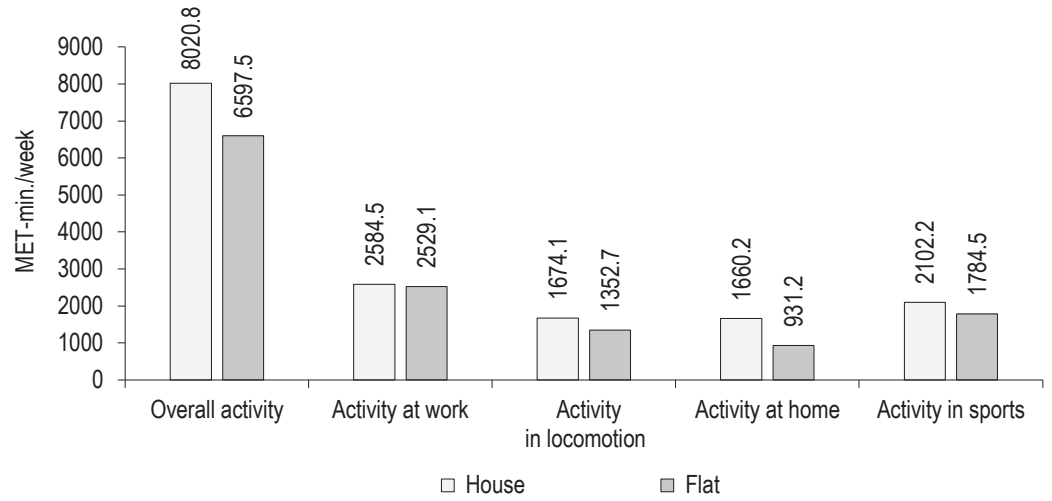

Figure 5 . Areas of physical activity of male students according to their place of residence

Tahle 3. Differentiation of the areas of physical activity of male students according to their place of residence

\begin{tabular}{|c|c|c|c|c|}
\hline \multicolumn{5}{|c|}{ Mann-Whitney U test } \\
\hline \multirow{2}{*}{ area of activity } & \multicolumn{2}{|c|}{ rank-sum } & \multirow{2}{*}{ Z } & \multirow{2}{*}{$p$} \\
\hline & house & flat & & \\
\hline Overall activity & 20,273 & 37,697 & -1.57 & 0.1155 \\
\hline Activity at work & 21,631 & 36,340 & -0.03 & 0.9794 \\
\hline Activity in locomotion & 20,844 & 37,126 & -0.92 & 0.3559 \\
\hline Activity at home & 17,579 & 40,391 & -4.65 & $0.0000^{*}$ \\
\hline Activity in sports & 20,780 & 37,190 & -1.00 & 0.3183 \\
\hline
\end{tabular}

Significant differentiation at $p<0.05$. 
Mann-Whitney $U$ test value: $Z=4.22 ; p=0.1214$

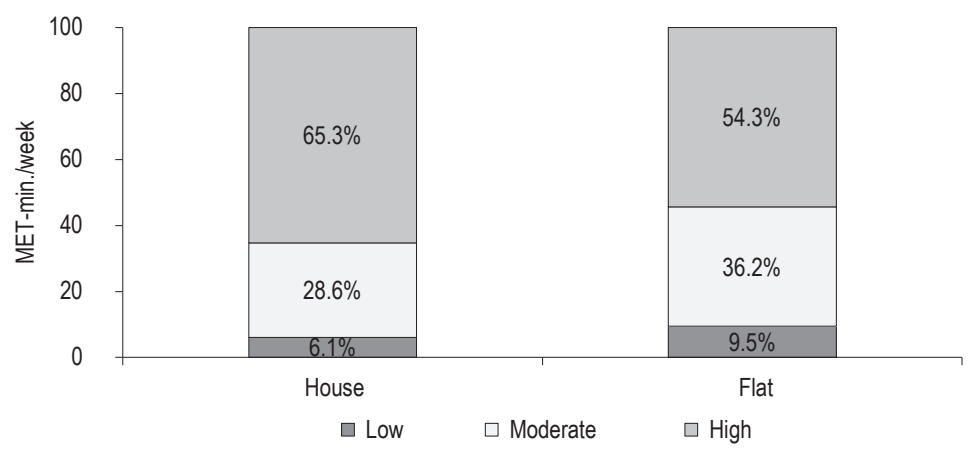

Figure 6. Level of physical activity of male students according to their place of residence

\section{The level of physical activity of female students}

The rate of overall physical activity of studying women was 5197.9 MET -min/week. However, no significance of differences between different areas of activity was revealed (Figure 7).

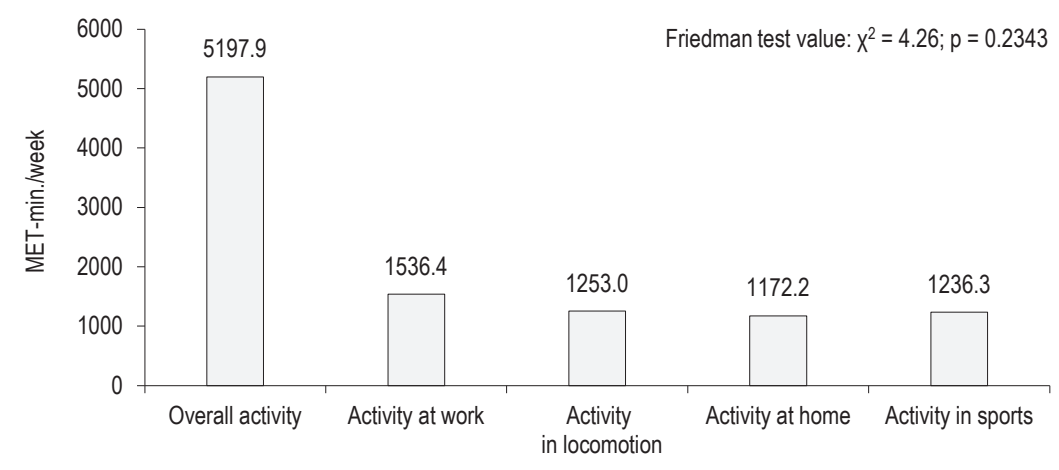

Figure 7. Areas of physical activity of female students

Women living in flats, as well as in houses, were characterized by similar overall physical activity, respectively 5324.2 MET-min/week and 4717.4 MET-min/week (no significant differences).

Statistically significant differences were observed in two areas, that is housework (in favour of women living in houses) and sports (in favour of women living in flats) (Figure 8, Table 4). 


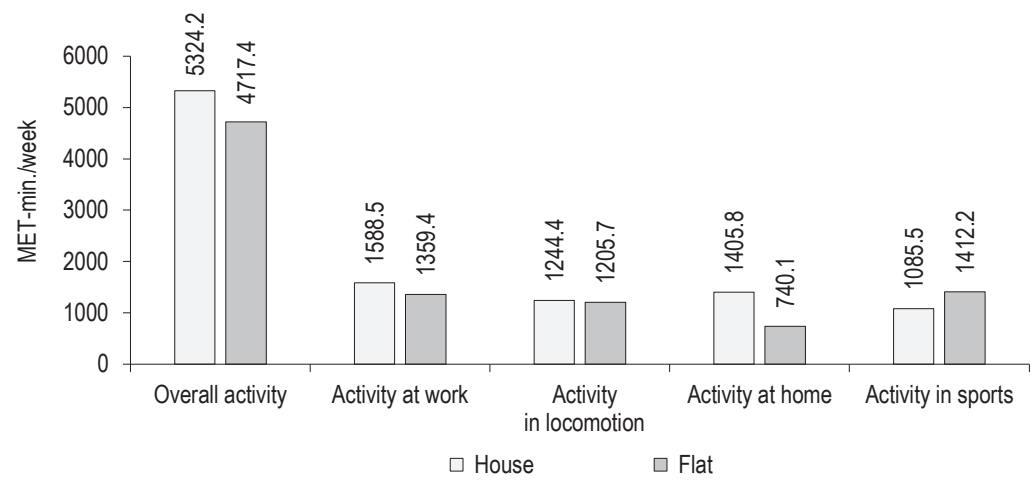

Figulp 8. Areas of physical activity of female students according to their place of residence

Table 4. Differentiation of the areas of physical activity of female students according to their place of residence

\begin{tabular}{|c|c|c|c|c|}
\hline \multirow{3}{*}{ area of activity } & \multicolumn{2}{|c|}{ Mann-Whitney U test } & \multirow{3}{*}{ Z } & \multirow{3}{*}{$p$} \\
\hline & \multicolumn{2}{|c|}{ rank-sum } & & \\
\hline & house & flat & & \\
\hline Overall activity & 20,770 & 42,421 & -0.84 & 0.4021 \\
\hline Activity at work & 20,686 & 42,505 & -0.94 & 0.3476 \\
\hline Activity in locomotion & 21,405 & 41,786 & -0.15 & 0.8846 \\
\hline Activity at home & 18,522 & 44,668 & -3.29 & $0.0010^{*}$ \\
\hline Activity in sports & 23,377 & 39,813 & 2.01 & $0.0442^{*}$ \\
\hline
\end{tabular}

Significant differentiation at $p<0.05$.

In three areas of physical activity no significant differences according to the place of residence were observed (Figure 9.)

Mann-Whitney $U$ test value: $Z=1.52 ; p=0.4672$

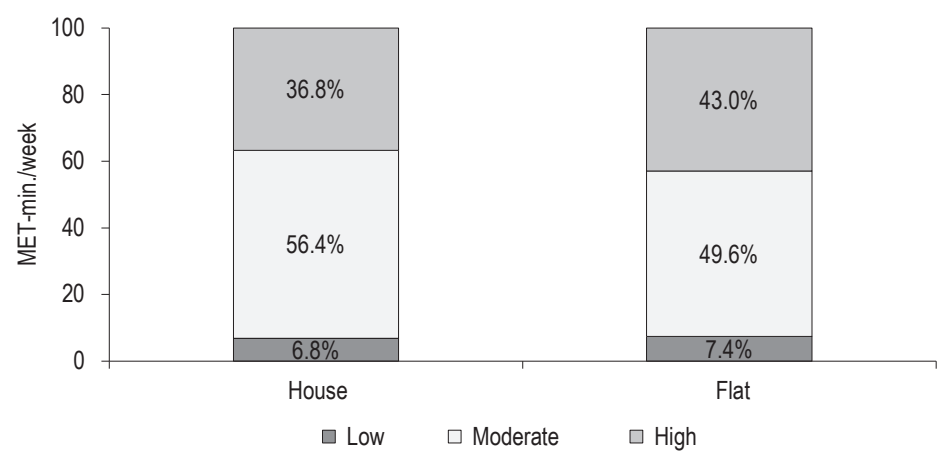

Figure 9. Level of physical activity of female students according to their place of residence 


\section{Discussion}

The students who took part in the research are characterized by high level of overall physical activity compared to other researches (Bergier et al., 2012; Biernat, 2011; Mynarski et al., 2009; Tsos et al., 2014). The research did not reveal significant differences in the level of overall physical activity according to the place of residence in both male and female students. It may result from the fact the available offer of physical activities does not differ according to the place of residence. Such a relation of higher physical activity was revealed in case of students from the USA living on the campus (Peachey, Baller, 2015). Multidirectional analysis of the relation of the living environment with the physical activity among German students did not show any significant dependencies (Baar et al., 2014).

However, it should be noticed that the analysis carried out revealed important relations between the fact of living in a house and higher physical activity as far as housework is concerned, what is more, this characteristic was present in both, male and female students. Therefore, it can be concluded that housework by virtue of place of residence is an important factor determining physical activity of students.

Also significantly higher activity in the area of sports and recreation among female students living in flats is worth mentioning, as no similar relation was found in male students which can be the reason of less healthy attitudes among male students as far as participation in physical activity is concerned.

\section{Conclusions}

The comparative analysis of the place of residence of students and their physical activity helped to formulate the following conclusions:

1. Students, according to their place of residence, are characterized by the lack of significance of differences in the level of their overall physical activity. This difference occurred however in the area of activity associated with the housework in favor of the group living in their family houses.

2. In male students the dominant area of physical activity is work / study and it is significantly higher than other areas.

3. There were no significant differences in overall physical activity of men according to the place of residence. Such a difference has been shown in the area of activity concerning household duties in favor of subjects living in family houses.

4. Additionally, as far as female students are concerned, no significant differences in the level of their total physical activity according to the place of residence were observed. Such differences have occurred in two areas of physical activity. Significantly higher values in terms of household duties were observed in subjects living in houses, while subjects living in flats (residential blocks) were more active in the area of sports. 


\section{References}

Ainsworth, B.E., Macera, C.A., Jones, D.A., Reis, J.P., Addy, C.L., Bowles, H.R., Kohl, H.W. (2006). Comparison of the 2001 BRFSS and the IPAQ Physical Activity Questionnaires. Med. Sci Sports Exerc, 38 (9): 1584-1592.

Baar, J., Romppel, M., Igel, U., Brahler, E., Grande, G. (2014). Associations Between the Residential Environmental and Physical Activity in German College Students and the Role of Self-Efficacy as a Mediator. Selbstwirksamkeitserwartung als Mediator der Zusammenhange von Wohnumgebung udn körperlicher Aktivitat Studierender. Zeitschrift für Gesundheits-psychologie, 3 , 118-128. DOI: 10.1026/0943-8149/a000120.

Bauman, A.E., Reis, R.S., Sallis, J.F., Wells, J.C., Loos, R.J.F., Martin, B.W. (2012). Correlates of physical activity: Why are some people physically active and others not? The Lancet, 380, 258-271. DOI: 10.1016/S0140-6736(16)00209-9. 403.

Bergier, J., Kubińska, Z., Bergier, B. (2011). Nurses' physical activity with respect to their education. Turystyka i Rekreacja, 8, 127-133.

Bergier, J., Kapka-Skrzypczak, L., Biliński, P., Paprzycki, P., Wojtyła, A. (2012). Physical activity of Polish adolescents and young adults according to IPAQ: a population based study. Ann Agric Environ Med, 19 (1), 109-115. 779. DOI: 10.5604/12321966.1185790.

Bergier, B., Stępień, E.J., Niźnikowska, E.A, Bergier, J. (2014). Aktywność fizyczna kobiet i mężczyzn studiujących w Państwowej Szkole Wyższej w Białej Podlaskiej. Medycyna Ogólna i Nauki o Zdrowiu, 20, 2, 166-170.

Bergier, J., Bergier, B., Tsos, A. (2014). Physical activity and eating habits among female students from Ukraine. Health Problems of Civilization, 9 (2), 5-12. DOI: 10.5114/hpc.2015.57117.

Bergier, B., Bergier, J., Tsos, A. (2015). Zachowania żywieniowe a aktywność fizyczna studentów ukraińskich. In: R. Stemplewski, R. Szeklicki, J. Maciaszka (eds.), Aktywność fizyczna i żywienie- w trosce o zdrowie i jakość życia. Poznań: Wydawnictwo Naukowe Bogucki.

Biernat, E. (2011). Aktywność fizyczna mieszkańców Warszawy. Na przykładzie wybranych grup zawodowych. Szkoła Główna Handlowa.

Brevard, P.B., Ricketts, C.D. (1996). Residence of College Student Affects Dietary Intake, Physical Activity, and Serum Lipid Levels. Journal of The American Dietetic Association [J Am Diet Assoc], Jan, 96 (1), 35-38.

Cerin, E., Vandelanotte, C., Leslie, E., Merom, D. (2008). Recreational facilities and leisure-time physical activity: An analysis of moderators and self-effcacy as a mediator. Health Psychology, 27, 126-135. DOI: 0.5114/hpr.2016.56606.

Crinière, L., Lhommet, C., Lecomte, P., Couet, C., Oppert, J.M., Jacobi, D. (2009). Validation du IPAQ français version longue chez les personnes diabétiques. Diabetes and Metabolism, 35, S50. DOI: 10.1111/dom.12636.

Ekelund, U., Sepp, H., Brage, S., Becker, W., Jakes, R., Hennings, M., Wareham, N.J. (2006). Criterion-related validity of the last 7-day, short form of the International Physical Activity Questionnaire in Swedish adults. Public Health Nutrition, 9 (4), 2, 258-265. DOI: 10.1079/PHN2005755.

Frömel, K., Górna, K. (2001). Aktywność ruchowa dzieci i młodzieży regionu śląskiego. In: W. Mynarski, M. Ponczek (ed.), Tradycje i współczesność kultury fizycznej. Katowice: AWF. DOI: 10.12775/v10251-012-0059.

Gómez, L.F., Duperly, J., Lucumí, D.I., Gamez, R., Venegas, A.S. (2005). Physical activity levels in adults living in Bogota (Columbia): prevalence and associated factors. Gac Sanit, 19, 206-213. DOI: 10.1157/13062528.

McCormack, G.R., Shiell, A. (2011 ). In search of causality: A systematic review of the relationship between the built environmental and physical activity among adults. International Journal of Behavioral Nutrition and Physical Activity, 8, 125-135. DOI: 10.1186/1479-5868-6-21.

Mynarski, W., Rozpara, M., Czapla, K., Garbaciak, W. (2009). Aerobic Capacity of studenst with Different Levels of Physical Activity as Assessed by IPAQ. Journal of Human Kinetics, 21, 89-96.

Peachey, A.A., Baller, S.L. (2015). Perceived Built Environment Characteristics of On-Campus and Off-Campus Neighborhoods Associated with Physical Activity of College Students. Journal of American College Health, 63 (5), 337-342. DOI: 10.1080/07448481.2015.1060597.

Pengpid, S., Peltzer, K. (2013). Physical inactivity and associated factors among university students in South Africa. African Journal for Physical, Health Education, Recreation and Dance (AJPHERD), 19 (1), 143-153. DOI: 10.1111/jonm.12065.

Sebastiao, E., Gobbi, S., Chodzko-Zajko, W., Schwindel, A., Papini, C.B.., Nakamura, P.M., Netto, A.V., Kokubun, E. (2012). The International Physical Activity Questionnaire-long form overestimates, self-reported physical activity of Brazilian adults. Public Health, 126 (11), 967-975. 
Soguksu, K. (2011). Physical activity level between Polish and Turkish university students (IPAQ). In: B. Bergier (ed.), Physical activity in health and disease (pp. 19-27). Pope John Paul II State School of Higher Education in Biała Podlaska.

Suchomel, A., Sigmundova, D., Frömel, K. (2008). The lifestyle of the inhabitants of the Liberec region. Human Movement, 9 (1), $19-26$.

Sygit, K. (2009). Physical activity of academic students. Central European Journal of Sport Sciences And Medicine, 25, 15-22.

Szczodrowska, A., Krysiak, W. (2013). Analiza wybranych zwyczajów żywieniowych oraz aktywności fizycznej studentów łódzkich szkół wyższych. Probl Hig Epidemiol, 94 (3), 518-521.

Tsos, A., Bergier, B., Bergier, J. (2014). Physical activity, physical development and eating habits within the lifestyles of students from Ukraine. Health Problems of Civilization, 8 (4), 46-53. DOI: 10.5114/hpc.2015.57117.

Cite this apticle aS: Bergier, J., Bergier, B., Niźnnikowska, E., Junger, J., Pongrác, Á., Frömel, K., Szepeluk, A. (2016). The Diversity of the Place of Residence of Students and their Level of Physical Activity. Central European Journal of Sport Sciences and Medicine, 13 (1), 123-132. DOI: 10.18276/cej.2016.1-13. 